\title{
Structure Investigations on Products from the Reaction of Organocopper, Organolithium and Organomagnesium Reagents with 2(1H)-Pyrimidinones
}

\author{
FRODE RISE, CHRISTIAN RØMMING and KJELL UNDHEIM
}

Department of Chemistry, University of Oslo, N-0315 Oslo 3, Norway

\begin{abstract}
Alkyl- and arylcuprates and alkyl- and aryllithium and -magnesium reagents form 3,4- or/and 3,6-adducts with 1-benzyl-2(1H)-pyrimidinones. The effect of 5-halo substituents on the reactivity and regioselectivity is reported. Structure analyses were made by NMR spectroscopy. Dehydrogenation gives the conjugated, substituted pyrimidinones. X-Ray crystallographic data for 1-benzyl-5-chloro-4-phenyl-2(1H)-pyrimidinone and its regioisomer 1-benzyl-5-chloro-6-phenyl-2(1H)-pyrimidinone are discussed.
\end{abstract}

Carbon substituents can be introduced into aromatic and heteroaromatic ring systems by cross-coupling reactions using organometallic reagents. In $\pi$-electron deficient heterocycles there exists an alternative route which involves initial adduct formation with the organometallic reagent and subsequent dehydrogenation of the dihydro intermediate. ${ }^{1}$ We herein report studies on carbon substitution in 1-substituted $2(1 \mathrm{H})$-pyrimidinones which are of biological interest as inhibitors of mitosis. ${ }^{2}$

The highly polarized pyrimidinones can add a carbon nucleophile at either C-4 or C-6 to form the corresponding 3,4- or 3,6-dihydro derivative. We report on the regioselectivity in such reactions using organocopper, organolithium and organomagnesium reagents. Previously we have found that the lithium enolate of acetophenone leads to exclusive carbon-carbon bond formation at C-4. ${ }^{3}$ 1-Alkyl-2(1H)-pyrimidinones with aryllithium reagents, and 1-alkyl-5-aryl-2(1H)-pyrimidinones in similar reactions are reported to give 3,4-adducts. ${ }^{4,5}$ With methylmagnesium iodide, however, the carbon-carbon bond formation is at $\mathrm{C}-6$, whereas methyllithium gives the 3,4 -adduct. ${ }^{6}$

In the reaction of the 1-benzyl-2(1H)-pyrimidinones 1 with the organometallic reagents the total yields of the adducts 2 and 4 were of the order 70-90\%. The reactions between the organolithium or organomagnesium reagent and $1 b$ or $1 c$ were fast, the reaction time being 10-15 min at room temperature. The reaction between $1 a$ and these reagents, however, had to be run for $24 \mathrm{~h}$. The lithium organocuprate reactions were run at $-78^{\circ} \mathrm{C}$. Again $1 a$ was much less reactive than $1 b$ and $1 c$. This suggests that the activating effect of the 5-halogen substituent due to its electronegativity is more important than the steric repulsion due to the size of the halogen atom toward attack at the vicinal 4- and 6-positions. The reaction is chemoselective in that the 5-halogen atom was not involved in any coupling reaction.

The relative yields of the isomers 2 and 4 are given in Table 1 . Complete regioselectivity was only observed for $2 b$ when it is formed from $1 a$ and methyllithium. With the lithium 
Table 1. The percentage composition of the products 2 and 4 . Relative yield (\%) of compound 2 .

\begin{tabular}{lrccc}
\hline & \multicolumn{4}{c}{ R-Metal } \\
\cline { 2 - 5 } Reagent & $5-\mathrm{H}$ & 5 -Cl & 5 - $\mathrm{Br}$ & 5 -I \\
\hline PhMgI & 8 & 10 & 34 & \\
MeMgI & 43 & 47 & 40 & 24 \\
PhLi & 8 & 75 & 75 & \\
MeLi & 100 & 72 & 63 & \\
$\mathrm{Ph}_{2} \mathrm{CuLi}$ & 85 & 23 & 29 & \\
$\mathrm{Me}_{2} \mathrm{CuLi}$ & 60 & 60 & 64 & 44 \\
\hline
\end{tabular}

reagents isomer 2 is the favoured product except for $2 a$. Formation of the other isomer 4 is favoured by the Grignard reagents. It is notable that the 3,6-dihydro isomer was favoured in the reaction of lithium diphenylcuprate with $1 b$ and $1 c$. In the other reactions of the organocuprate reagents isomer 2 is the major product. Compound $1 d$ would only form adducts with methylmagnesium iodide and lithium dimethylcuprate; the low reactivity is attributed to the bulky iodine substituent and its relatively low electronegativity.

In the dehydrogenation of 2 and 4 to the fully conjugated pyrimidinones, 3 and 5 activated manganese dioxide ${ }^{7}$ was used. In the case of $2 c$ the reaction was complete after 24 $\mathrm{h}$ at room temperature, whereas the reaction of its 6-phenyl isomer $4 c$ had to be run for 13 days. In the dehydrogenation of the 4-methyl derivative $2 d$ to its 4-methylpyrimidinone $3 d$, difficulties were experienced because of low stability of the dihydropyrimidinone. Furthermore, the methyl group in the final product $3 d$ is highly activated by the electron deficiency of the heterocyclic ring and polymerization therefore readily occurs under the conditions of the reaction. The 6-methyl derivative $4 d$ was dehydrogenated very slowly and was largely polymerized.

The assignments of the dihydro products as 2 and 4 are based on spectroscopy. In the case of the phenyl derivatives $2 c$ and $4 c$, their structures have been firmly established by $\mathrm{X}$-ray crystallographic analysis after dehydrogenation which gave $3 c$ and $5 c$.

In the adduct formation a chiral carbon is introduced where the $\mathrm{R}$ group becomes attached. The isomer pairs fall into two patterns which in the ${ }^{1} \mathrm{H}$ NMR spectrum shows a characteristic difference for the diastereotopic methylene protons of the benzyl group; a singlet in 2 and an AB pattern, $J_{\text {gem }} 15-18 \mathrm{~Hz}$, in 4 . The splitting of the signal from the methylene protons in isomer 4 may be attributed to the proximity of these protons to the chiral centre at C-6. The spin couplings in the pyrimidine ring constitute another characteristic difference between the two series. Thus in $4 c \mathrm{H}-4$ at $6.29 \mathrm{ppm}$ is spin coupled to the amino proton $\mathrm{H}-3$ at $8.63 \mathrm{ppm}(\mathrm{J} 4 \mathrm{~Hz})$, whereas the corresponding olefinic proton $\mathrm{H}-6$ in $2 c$ resonates as a singlet. Homonuclear nOe can be observed in $4 c$. Irradiation of the amino proton $\mathrm{H}-3$ gave nOe at $\mathrm{H}-4$. Irradiation of $\mathrm{H}-6$ gave an effect at the upfield proton (3.51 ppm) of the methylene AB system, whereas a negative effect was observed at the other proton $(6.32 \mathrm{ppm})$, possibly because of its proximity to the irradiation frequency. Irradiation of the upfield methylene proton gave an effect at its downfield partner with a small effect on $\mathrm{H}-6$; very small effects on $\mathrm{H}-3$ and $\mathrm{H}-4$ were observed.

In the fully conjugated pyrimidinone $3 c$, H-6 resonates at a higher field ( $7.69 \mathrm{ppm})$ than $\mathrm{H}-4(8.65 \mathrm{ppm})$ in its isomer $5 c$. The higher deshielding at C-4 than at C-6 appears to be general in this class of compounds as shown by selective homonuclear proton nOe 
experiments. Thus the assignment of the doublets in the spectrum of $1 b$ at 8.52 and $7.59 \mathrm{ppm}$ $(J 3.42 \mathrm{~Hz})$ to $\mathrm{H}-4$ and $\mathrm{H}-6$, respectively, follows from the change in the spectrum on irradiation at the methylene protons at $5.08 \mathrm{ppm}$. The difference spectrum obtained shows a significant signal at the 7.59 doublet, but no discernible signal at the $8.52 \mathrm{ppm}$ doublet, which therefore must be assigned to $\mathrm{H}-4$. The intensity enhancement is estimated to be 8-10\%. Similarly, in the parent compound $1 a$ application of the same technique led to the assignments of the signals at $8.57 \mathrm{ppm}$ to $\mathrm{H}-4$ and $7.59 \mathrm{ppm}$ to $\mathrm{H}-6$.

$\mathrm{X}$-Ray crystallographic analysis has been carried out on the isomers $3 c$ and $5 c$. Final fractional coordinates are given in Table 2. Structural data are listed in Table 3 and ORTEP drawings of $3 c$ and $5 c$ are presented in Fig. 1. The numbering of the atoms corresponds to that given in the tables.

A comparison of the data in Table 3 with the corresponding data for $2(1 H)$-pyrimidinone $^{8}$ and $1-\beta$-ribosyl-2(1H)-pyrimidinone ${ }^{9}$ shows that the bond lengths and angles in these 2(1H)-pyrimidinones are similar. The 5-chloro substituent in $3 c$ and $5 c$ leads to a relative widening of the $\mathrm{C} 4-\mathrm{C} 5-\mathrm{C} 6$ angle. A phenyl group leads to a relative reduction of the angle of the carbon to which it is attached, viz. N3-C4-C5 for $3 c$ and $\mathrm{C} 5-\mathrm{C} 6-\mathrm{N} 1$ for $5 c$. In $5 c$ the angle is $75.5^{\circ}$ between the planes of the pyrimidine ring and the 6-phenyl ring. The phenyl ring of the 1-benzyl group is also outside the pyrimidine plane, the 1- and 6-substituents assuming a sandwich like structure (Fig. 1). In the crystalline state the plane of the 4-phenyl group in $3 c$ is inclined $63.2^{\circ}$ to the plane of the pyrimidine ring, which may be caused by the 5 -chloro substituent.

Table 4 shows estimated $\pi$-bond orders for $3 c$ and $5 c .{ }^{10} \mathrm{~A}$ comparison of the bond orders for the two isomers shows a relative reduction in the $\pi$-bond order for the N3-C4 and

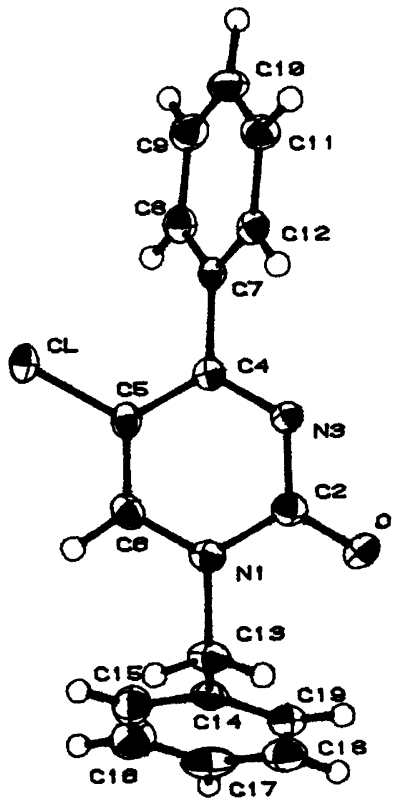

$3 \mathrm{c}$

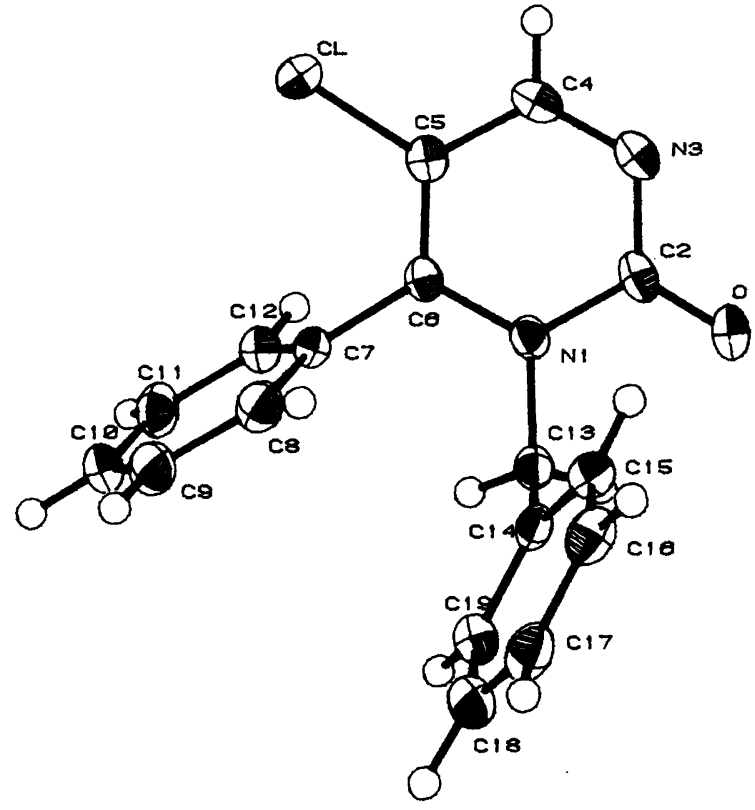

$5 c$

Fig. 1. ORTEP plots of $3 c$ and $5 c$.

Acta Chem. Scand. B 39 (1985) No. 6 


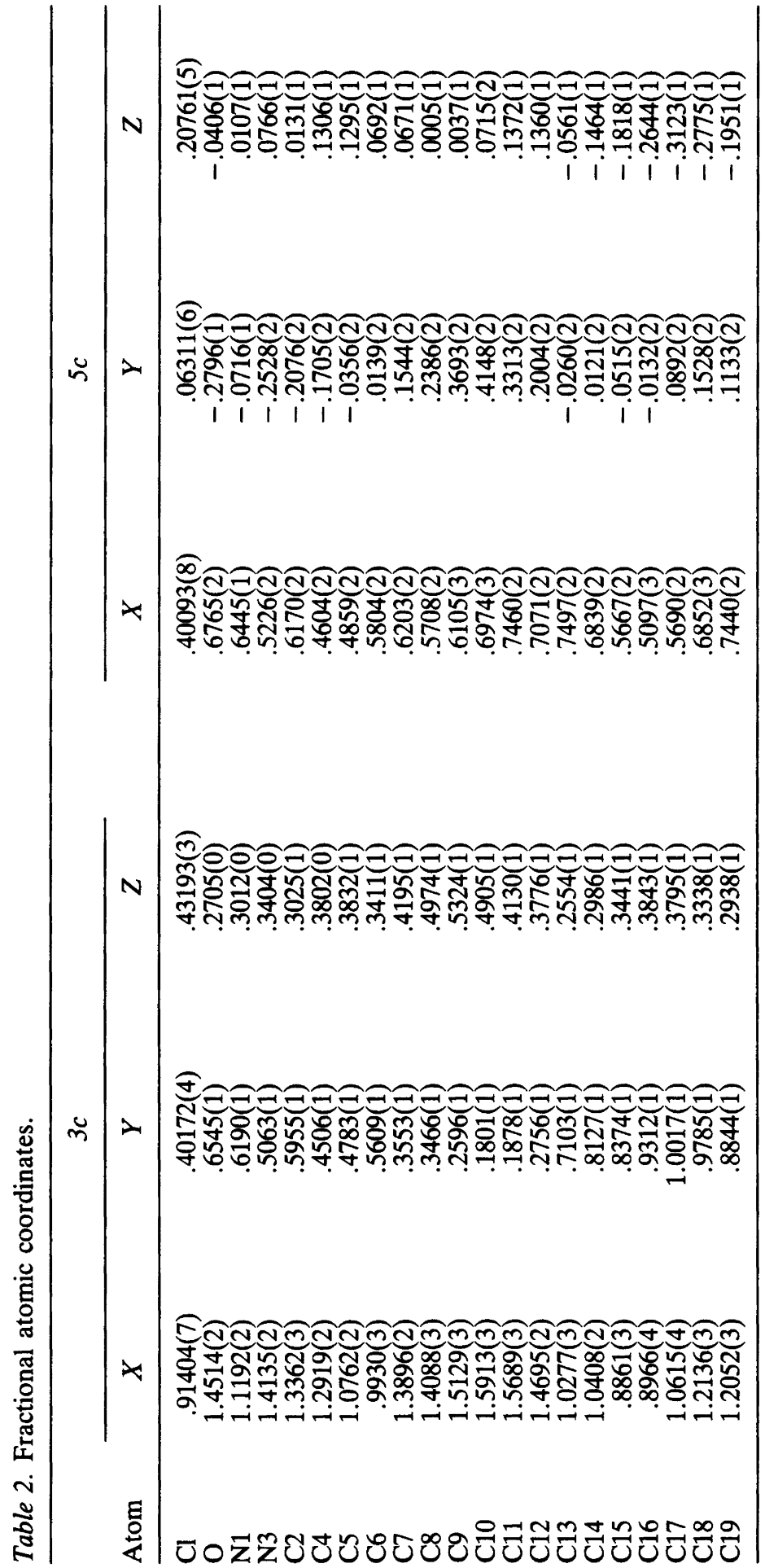

Acta Chem. Scand. B 39 (1985) No. 6 
Table 3. Bond distances and angles with estimated standard deviation.

\begin{tabular}{|c|c|c|c|c|}
\hline & & $3 c$ & $5 c$ & $\Delta / \sigma$ \\
\hline Distance $(\AA)$ & $\begin{array}{l}\mathrm{C} 5-\mathrm{Cl} \\
\mathrm{C} 2-\mathrm{O} \\
\mathrm{N} 1-\mathrm{C} 2 \\
\mathrm{C} 2-\mathrm{N} 3 \\
\mathrm{~N} 3-\mathrm{C} 4 \\
\mathrm{C} 4-\mathrm{C} 5 \\
\mathrm{C} 5-\mathrm{C} 6 \\
\mathrm{C} 6-\mathrm{N} 1 \\
\mathrm{C} 4(6)-\mathrm{C} 7 \\
\mathrm{~N} 1-\mathrm{C} 13 \\
\mathrm{C}-\mathrm{C} \text { (phenyl) }\end{array}$ & $\begin{array}{l}1.726(2) \\
1.234(2) \\
1.401(2) \\
1.371(2) \\
1.317(2) \\
1.416(3) \\
1.353(3) \\
1.355(2) \\
1.489(3) \\
1.488(2) \\
1.386\end{array}$ & $\begin{array}{l}1.731(3) \\
1.220(3) \\
1.421(3) \\
1.372(3) \\
1.301(3) \\
1.407(3) \\
1.358(3) \\
1.371(3) \\
1.491(3) \\
1.475(3) \\
1.387\end{array}$ & $\begin{array}{l}1.4 \\
3.9 \\
5.6 \\
0.3 \\
4.4 \\
2.1 \\
1.2 \\
4.4 \\
0.5 \\
3.6\end{array}$ \\
\hline Ring angle $\left({ }^{\circ}\right)$ & $\begin{array}{l}\mathrm{C} 6-\mathrm{N} 1-\mathrm{C} 2 \\
\mathrm{~N} 1-\mathrm{C} 2-\mathrm{N} 3 \\
\mathrm{C} 2-\mathrm{N} 3-\mathrm{C} 4 \\
\mathrm{~N} 3-\mathrm{C} 4-\mathrm{C} 5 \\
\mathrm{C} 4-\mathrm{C} 5-\mathrm{C} 6 \\
\mathrm{C} 5-\mathrm{C} 6-\mathrm{N} 1\end{array}$ & $\begin{array}{l}121.2(2) \\
117.9(2) \\
120.7(2) \\
121.4(2) \\
118.4(2) \\
120.0(2)\end{array}$ & $\begin{array}{l}122.2(2) \\
117.9(2) \\
119.4(2) \\
123.8(3) \\
119.3(2) \\
117.5(2)\end{array}$ & $\begin{array}{l}3.6 \\
0 \\
4.6 \\
6.7 \\
3.2 \\
8.9\end{array}$ \\
\hline Torsion angle $\left({ }^{\circ}\right)$ & $\begin{array}{l}\mathrm{C} 6-\mathrm{N} 1-\mathrm{C} 2-\mathrm{N} 3 \\
\mathrm{~N} 1-\mathrm{C} 2-\mathrm{N} 3-\mathrm{C} 4 \\
\mathrm{C} 2-\mathrm{N} 3-\mathrm{C} 4-\mathrm{C} 5 \\
\mathrm{~N} 3-\mathrm{C} 4-\mathrm{C} 5-\mathrm{C} 6 \\
\mathrm{C} 4-\mathrm{C} 5-\mathrm{C} 6-\mathrm{N} 1 \\
\mathrm{C} 5-\mathrm{C} 6-\mathrm{N} 1-\mathrm{C} 2 \\
\mathrm{~N} 1-\mathrm{C} 13-\mathrm{C} 14-\mathrm{C} 15 \\
\mathrm{~N} 1-\mathrm{C} 13-\mathrm{C} 14-\mathrm{C} 19 \\
\text { Pyrimid. }-\mathrm{C} 7-\mathrm{C} 12^{a}\end{array}$ & $\begin{array}{r}5.3(3) \\
-6.4(3) \\
2.3(3) \\
3.2(3) \\
-4.2(3) \\
0.0(3) \\
-83.4(2) \\
97.0(2) \\
63.2\end{array}$ & $\begin{array}{r}0.0(5) \\
1.2(4) \\
-1.2(5) \\
-0.1(5) \\
1.3(4) \\
-1.3(4) \\
-34.0(3) \\
146.1(2) \\
75.5\end{array}$ & \\
\hline
\end{tabular}

${ }^{a}$ The angle between the plane of the pyrimidine ring and the plane of the phenyl ring.

Table 4. Estimated $\pi$-bond order. ${ }^{a}$

\begin{tabular}{llll}
\hline Bond & $3 c$ & $5 c$ \\
\hline N1-C2 & 0.32 & & 0.21 \\
C2-N3 & & 0.48 & 0.48 \\
N3-C4 & 0.78 & 0.87 \\
C4-C5 & 0.56 & 0.61 \\
C5-C6 & 0.91 & 0.88 \\
C6-N1 & 0.57 & 0.48 \\
\hline
\end{tabular}

${ }^{a} R(\mathrm{CC})=1.517-0.18 p ; R(\mathrm{CN})=1.458-0.18 p .^{10}$

$\mathrm{C} 4-\mathrm{C} 5$ bonds in $3 c$; in $5 c$ the relative reduction is in the bond orders for $\mathrm{C} 5-\mathrm{C} 6$ and $\mathrm{C} 6-\mathrm{N} 1$, but also in the $\mathrm{N} 1-\mathrm{C} 2$ bond.

The pyrimidine ring in the 6-phenyl isomer $5 c$ is closer to planarity than the pyrimidine ring in the 4-phenyl isomer $3 c$ (Table 3). 


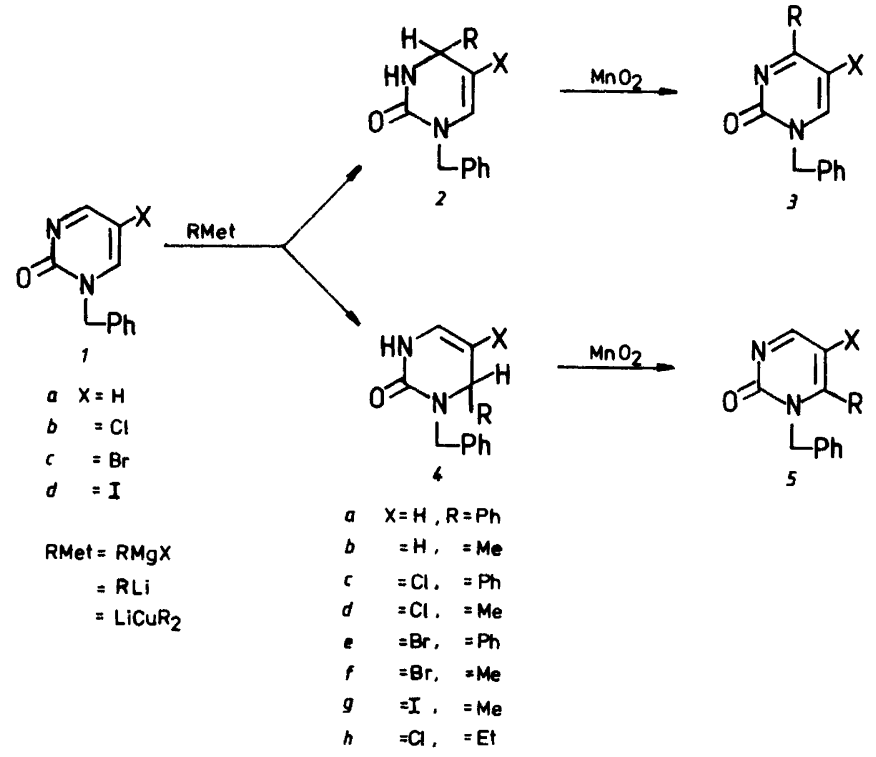

Scheme 1 .

\section{EXPERIMENTAL}

$X$-Ray crystallography. The compounds $3 c$ and $5 c$ were crystallized from ethyl acetate. Data were collected on a NICOLET $P 3 / F$ four circle diffractometer, MoK $\alpha$ radiation $(\lambda=0.71069$ $\AA)$. The temperature at the crystal site was kept at $-130^{\circ} \mathrm{C}$; specimen dimensions $0.3 \times 0.3 \times 0.3 \mathrm{~mm}(3 c)$ and $0.2 \times 0.3 \times 0.3 \mathrm{~mm}(5 c)$. The $\omega$-scan mode was employed with scan speed $3-6^{\circ} \mathrm{min}^{-1}$ depending on the intensity, and scan ranges $1^{\circ}(3 c)$ and $0.8^{\circ}(5 c)$. For $3 c$ 2495 reflections with $\sin \theta / \lambda<0.5 \AA^{-1}$ were measured; of these 1979 had $I / \sigma(I)>2.5$ and were used for the structure analysis. For $5 c 2060$ reflections with $\sin \theta / \lambda<0.7 \AA^{-1}$ were measured; of these 1921 were actually used in the analysis. The intensity data were corrected for Lorentz and polarization effects; no absorption or extinction corrections were applied. The atomic scattering factors were those of Doyle and Turner, ${ }^{11}$ except for hydrogen $;{ }^{12}$ the computer programs have been described by Groth. ${ }^{13}$

\section{Crystal data}

1-Benzyl-5-chloro-4-phenyl-2 $(1 \mathrm{H})$-pyrimidinone, $\mathrm{C}_{17} \mathrm{H}_{13} \mathrm{ClN}_{2} \mathrm{O}$, monoclinic, cell dimensions $a=6.323(1) \AA ; b=12.606(3) \AA ; c=17.973(4) \AA ; \beta=97.31(2)^{\circ} ; V=1420.9 \AA^{3}\left(t=-130^{\circ} \mathrm{C}\right)$. $F(000)=616 ; Z=4 ; M=296.76 ; D_{\mathrm{x}}=1.387 \mathrm{~g} \mathrm{~cm}^{-3} ; \mu(\mathrm{MoK \alpha})=2.73 \mathrm{~cm}^{-1}$. Absent reflections: $h 0 l$ for $l$ odd, $0 k 0$ for $k$ odd. Space group $P 2_{1} / c$ (No. 14).

1-Benzyl-5-chloro-6-phenyl-2 $(1 \mathrm{H})$-pyrimidinone, $\quad \mathrm{C}_{17} \mathrm{H}_{13} \mathrm{ClN}_{2} \mathrm{O}, \quad$ orthorhombic, $a=9.452(3) \AA ; b=10.270(4) \AA ; c=14.724(9) \AA ; V=1429.3 \AA^{3}\left(t=-130{ }^{\circ} \mathrm{C}\right) . F(000)=616$; $Z=4, M=296.76 ; D_{\mathrm{x}}=1.369 \mathrm{~g} \mathrm{~cm}^{3}, \mu(\mathrm{MoK} \alpha)=2.71 \mathrm{~cm}^{-1}$. Absent reflections $h 00$ for $h$ odd, $0 k 0$ for $k$ odd, $00 l$ for $l$ odd. Space group $p_{2} 2_{1} 2_{1}$ (No. 19).

Structure determination. The structures were solved by direct methods ${ }^{14}$ and refined by full-matrix least-squares calculations. Non-hydrogen atoms were given anisotropic temperature factors; hydrogen atomic positions were calculated from steric considerations and refined using isotropic temperature factors. Weights for the least-squares calculations were the inverse of the variance of the observed intensities, taken as $\sigma^{2}(I)=C_{\mathrm{T}}+\left(0.03 C_{\mathrm{N}}\right)^{2}$, where $C_{\mathrm{T}}$ is the total number of counts and $C_{\mathrm{N}}$ is the net count. The refinement terminated with 
conventional $R$-values of $0.034(3 c)$ and $0.039(5 c)$, weighted $R$-values of $0.039(3 c)$ and $0.040(5 c)$, and $S$-values of $1.51(3 c)$ and $1.36(5 c) .\left(S=\left[\Sigma w(\Delta F)^{2} /(n-m)\right]^{\frac{1}{2}}\right)$. Final fractional coordinates are given in Table 2 and structural data in Table 3; estimated standard deviations are calculated from the variance-covariance matrix.

Hydrogen and thermal parameters and the structure factor listing may be obtained from the authors (C.R.).

Mass spectra. The mass spectra were obtained by chemical ionization using isobutane, MS(B), or methane, MS(M), and also by electron bombardment at $70 \mathrm{eV}, \mathrm{MS}$. The spectra are given as $m / z$ (\% rel. int.).

NMR spectra. The ${ }^{1} \mathrm{H}$ NMR spectra were recorded at $60 \mathrm{MHz}$ unless otherwise stated, and the ${ }^{13} \mathrm{C}$ NMR spectra at $15 \mathrm{MHz}$ on a JMN-FZ 60 Fourier transform spectrometer.

The homonuclear nOe experiments were performed using low power irradiation where the irradiation was gated off during the acquisition period. Difference nOe spectra were obtained by performing an identical acquisition, except that the irradiation frequency was shifted to a position where no resonances were to be found.

The pulse angle was $60^{\circ}$, acquisition time $4.09 \mathrm{~s}$, delay of irradiation $4.0 \mathrm{~s}$. Ambient temperature. The spectral resolution was $0.244 \mathrm{~Hz} /$ point.

1-Benzyl-2(1H)-pyrimidinone 1a. ${ }^{1} \mathrm{H}$ NMR $\left.(100 \mathrm{MHz} ; 7.1 \mathrm{mg} \text { in } 0.4 \mathrm{ml} \mathrm{CDCl})_{3}\right): \delta 5.106$ $\left(\mathrm{CH}_{2} \mathrm{Ph}, \mathrm{s}\right), 6.260$ (H-5, dd, $\left.J_{5,6} 6.60 \mathrm{~Hz}, J_{5,4} 4.03 \mathrm{~Hz}\right), 7.358(\mathrm{Ph}, \mathrm{s}), 7.590\left(\mathrm{H}-6\right.$, dd, $J_{6,5} 6.60$ $\left.\mathrm{Hz}, J_{6,4} 2.93 \mathrm{~Hz}\right), 8.574\left(\mathrm{H}-4, J_{4,5} 4.03 \mathrm{~Hz}, J_{4,6} 2.93 \mathrm{~Hz}\right)$. Significant signals were observed for all of the ring protons in a difference nOe experiment on irradiation of the methylene protons at $5.106 \mathrm{ppm}$, but the intensities of the signals were $\mathrm{H}-6>\mathrm{H}-5>\mathrm{H}-4$.

1-Benzyl-5-chloro-2(1H)-pyrimidinone ${ }^{15}$ 1b. ${ }^{1} \mathrm{H}$ NMR $(100 \mathrm{MHz} ; 38 \mathrm{mg}$ in ca. $0.4 \mathrm{ml}$ $\left.\mathrm{CHCl}_{3}\right) ; \delta 5.08\left(\mathrm{CH}_{2} \mathrm{Ph}, \mathrm{s}\right), 7.39(\mathrm{Ph}, \mathrm{s}), 7.59\left(\mathrm{H}-6, \mathrm{~d}, J_{6,4} 3.41 \mathrm{~Hz}\right), 8.52\left(\mathrm{H}-4, \mathrm{~d}, J_{4,6} 3.42\right.$ $\mathrm{Hz}$ ). The difference spectrum obtained with irradiation at the methylene protons at 5.08 shows a significant signal at the $7.59 \mathrm{ppm}$ doublet $(\mathrm{H}-6)$, but no discernible signal at the 8.52 ppm doublet $(\mathrm{H}-4)$; intensity enhancement 8-10\%.

1-Benzyl-2(1H)-pyrimidinone 1a. Benzyl bromide $(75 \mathrm{mmol})$ was added to a solution of 2-pyrimidinone hydrochloride $(75 \mathrm{mmol})$ and triethylamine $(150 \mathrm{mmol})$ in dichloromethane (2.5 $\mathrm{l})$ and the mixture stirred at room temperature for $5 \mathrm{~h}$. The reaction mixture was then extracted with water $(3 \times 100 \mathrm{ml})$, the dried $\left(\mathrm{MgSO}_{4}\right)$ solution evaporated, the residue triturated with ether and finally recrystallized from ethyl acetate; yield $60 \%$, m.p. $1388^{\circ} \mathrm{C}$. Anal. $\mathrm{C}_{11} \mathrm{H}_{10} \mathrm{~N}_{2} \mathrm{O}: \mathrm{C}, \mathrm{H}$. ${ }^{1} \mathrm{H}$ NMR $\left(\mathrm{CDCl}_{3}\right): \delta 5.13\left(\mathrm{CH}_{2} \mathrm{Ph}\right), 6.33\left(\mathrm{H}-5\right.$, dd, $\left.J_{4,5} 4 \mathrm{~Hz}\right), 7.40$ $(\mathrm{Ph}), 7.59$ (H-6, dd, $\left.J_{4,5} 6 \mathrm{~Hz}, J_{4,6} 2.5 \mathrm{~Hz}\right), 8.57(\mathrm{H}-4, \mathrm{~m})$. MS: $186(68, \mathrm{M}), 185(13), 91(100)$.

1-Benzyl-5-bromo-2 $(1 \mathrm{H})$-pyrimidinone $1 \mathrm{c}$ was synthesized as above from 5-bromo$2(1 \mathrm{H})$-pyrimidinone; yield $50 \%$, m.p. $215^{\circ} \mathrm{C}\left(\mathrm{CHCl}_{3}\right)$. Anal. $\mathrm{C}_{11} \mathrm{H}_{9} \mathrm{BrN}_{2} \mathrm{O}: \mathrm{C}, \mathrm{H}$. ${ }^{1} \mathrm{H}$ NMR $\left(\mathrm{CDCl}_{3}\right): \delta 4.98\left(\mathrm{CH}_{2} \mathrm{Ph}\right), 7.30(\mathrm{Ph}), 7.56(\mathrm{H}-6, \mathrm{~d}, \mathrm{~J} 3 \mathrm{~Hz}), 8.43(\mathrm{H}-4, \mathrm{~d})$.

1-Benzyl-5-iodo-2 $(1 \mathrm{H})$-pyrimidinone $1 \mathrm{~d}$. Benzyl bromide $(4.5 \mathrm{mmol})$ was added to a solution from 5-iodo-2 $(1 \mathrm{H})$-pyrimidinone $(4.5 \mathrm{mmol})$ and potassium tert-butoxide $(4.5$ $\mathrm{mmol})$ in dry DMF $(100 \mathrm{ml})$ and the mixture stirred for $2 \mathrm{~d}$ at room temperature. The solvent was then distilled off at reduced pressure, the residue extracted with chloroform, the washed and dried $\left(\mathrm{MgSO}_{4}\right)$ chloroform solution evaporated and the residue crystallized from ethyl acetate, m.p. $220{ }^{\circ} \mathrm{C}$; yield $48 \%$. Anal. $\mathrm{C}_{11} \mathrm{H}_{9} \mathrm{IN}_{2} \mathrm{O} . \mathrm{C}, \mathrm{H} .{ }^{1} \mathrm{H}$ NMR $\left(\mathrm{CDCl}_{3}\right): \delta$ $5.00\left(\mathrm{CH}_{2} \mathrm{Ph}\right), 7.53(\mathrm{H}-6, \mathrm{~d}, \mathrm{~J} 2 \mathrm{~Hz}), 8.61(\mathrm{H}-4, \mathrm{~d})$. MS(B): $313(100, \mathrm{M}+\mathrm{H})$.

General procedures for the preparation of 1-benzyl-3,4-dihydro-4-substituted-2(1H)pyrimidinone 2 and 1-benzyl-3,6-dihydro-6-substituted-2(1H)-pyrimidinone 4: Method A. Grignard reagent. The 1-benzyl-2(1H)-pyrimidinone $(2.7 \mathrm{mmol})$ was added to an ethereal solution $(100 \mathrm{ml})$ of phenyl- or methylmagnesium iodide with stirring at room temperature. The mixture was stirred at room temperature for 10-15 min except for the reactions of $1 a$ which were run for $24 \mathrm{~h}$. Excess organometallic reagent was destroyed by the addition of dilute hydrochloric acid. The two phases were separated, the aqueous phase extracted with ether, the combined ether solution shaken with saturated aqueous ammonium chloride $(2 \times 10 \mathrm{ml})$, with saturated aqueous sodium hydrogen carbonate $(2 \times 10 \mathrm{ml})$, with water, the dried $\left(\mathrm{MgSO}_{4}\right)$ ether solution evaporated, and the 3,4-dihydro and the 3,6-dihydro isomers separated by column chromatography on neutral alumina, activity II. The former isomer is initially eluated by chloroform.

Method B. Organolithium reagent: $1.8 \mathrm{M}$ ethereal $(2.5 \mathrm{ml})$ phenyl- or methyllithium $(4.5$ $\mathrm{mmol}$ ) was added dropwise with stirring over 10-15 min to an ethereal solution (100 $\mathrm{ml})$ of 
the 1-benzyl-2(1H)-pyrimidinone $(2.3 \mathrm{mmol})$ under nitrogen. The mixture was kept at room temperature during the addition by external cooling of the exothermic reaction. The mixture was stirred for $5 \mathrm{~min}$ after the addition was complete and worked up as described above. The reactions of $1 a$, however, were allowed to proceed for $24 \mathrm{~h}$.

Method $C$. Cuprate reagent. The 1-benzyl-2(1H)-pyrimidinone $(1.9 \mathrm{mmol})$ was added to a stirred ethereal solution $(100 \mathrm{ml})$ of lithium diphenyl- or dimethylcuprate $(5.9 \mathrm{mmol})$ at $-78^{\circ} \mathrm{C}$. The stirred mixture was allowed to reach room temperature, and the stirring continued for another $2 \mathrm{~h}$ before the mixture was worked up as above. The reaction between $1 a$ and the phenyl reagent, however, was allowed to proceed for $24 \mathrm{~h}$.

1-Benzyl-3,4-dihydro-4-phenyl-2(1H)-pyrimidinone $2 \mathrm{a}$ and 1-benzyl-3,6-dihydro-6phenyl-2(1H)-pyrimidinone $4 \mathrm{a}$. Method $A$. The reaction with $1 a^{15}$ was allowed to proceed for $24 \mathrm{~h}$ at room temperature. The dihydro isomers were separated by chromatography on alumina. The yield was $7 \%$ of $2 a$ and $81 \%$ of $4 a$.

Physical data for $2 a$ : M.p. $222-223{ }^{\circ} \mathrm{C}$ (EtOAc). Anal. $\mathrm{C}_{17} \mathrm{H}_{16} \mathrm{~N}_{2} \mathrm{O}$ : C, H. ${ }^{1} \mathrm{H}$ NMR $\left(\mathrm{CDCl}_{3}\right): \delta 4.67\left(\mathrm{CH}_{2} \mathrm{Ph}\right), 4.83(\mathrm{H}-4, \mathrm{~m}), 5.17(\mathrm{H}-5, \mathrm{~m}), 5.97\left(\mathrm{H}-6, \mathrm{~d}, J_{5,6} 8 \mathrm{~Hz}\right), 6.18(\mathrm{NH})$. MS(B): $265(4, \mathrm{M}+\mathrm{H}), 175(100)$.

Physical data for $4 a$ : M.p. $166{ }^{\circ} \mathrm{C}$ (EtOAc). Anal. $\mathrm{C}_{17} \mathrm{H}_{16} \mathrm{~N}_{2} \mathrm{O}: \mathrm{C}, \mathrm{H} .{ }^{1} \mathrm{H}$ NMR $\left(\mathrm{CDCl}_{3}\right)$ : $\delta 3.53$ and $5.37\left(\mathrm{CH}_{2} \mathrm{Ph}, J 15 \mathrm{~Hz}\right), 4.5-4.9(\mathrm{H}-4, \mathrm{H}-5, \mathrm{~m}), 6.08(\mathrm{H}-6, \mathrm{dd}), 8.08(\mathrm{NH}, \mathrm{d}, J 3$ $\mathrm{Hz})$. MS(M): $265(100, \mathrm{M}+\mathrm{H})$.

Method $B$. The reaction was allowed to proceed for $24 \mathrm{~h}$ at room temperature. The yield of the isomer mixture was $81 \%$, relative composition $8 \%$ of $2 a$ and $92 \%$ of $4 a$. ( ${ }^{1} \mathrm{H}$ NMR).

Method $C$. The reaction mixture was stirred for $24 \mathrm{~h}$ after reaching room temperature. The yield of the isomer mixture was $80 \%$, relative composition $85 \%$ of $2 a$ and $15 \%$ of $4 a$ ( ${ }^{1} \mathrm{H}$ NMR).

1-Benzyl-3,4-dihydro-4-methyl-2(1H)-pyrimidinone $2 \mathrm{~b}$ and 1-benzyl-3,6-dihydro-6methyl-2(1H)-pyrimidinone $4 \mathrm{~b}$. Method $A$. The reaction with $1 a^{15}$ was allowed to proceed at room temperature for $24 \mathrm{~h}$. The isomers were separated on neutral alumina. The yield of $2 b$ was $34 \%$ and of $4 b 45 \%$.

Physical data for $2 b$ : M.p. $113-115^{\circ} \mathrm{C}$ (EtOAc). Anal. $\mathrm{C}_{12} \mathrm{H}_{14} \mathrm{~N}_{2} \mathrm{O}$ : C, H. ${ }^{1} \mathrm{H}$ NMR $\left(\mathrm{CDCl}_{3}\right): \delta 1.22(4-\mathrm{Me}, \mathrm{d}, J 6 \mathrm{~Hz}), 4.23(\mathrm{H}-4, \mathrm{~m}), 4.6\left(\mathrm{CH}_{2} \mathrm{Ph}\right), 4.73(\mathrm{H}-5, \mathrm{~m}), 5.90(\mathrm{H}-6, \mathrm{~d}$, $J 8 \mathrm{~Hz}), 6.17(\mathrm{NH}) . \mathrm{MS}(\mathrm{B}): 203(100, \mathrm{M}+\mathrm{H})$.

Physical data for $4 b$ : Non-crystalline material. ${ }^{1} \mathrm{H}$ NMR $\left(\mathrm{CDCl}_{3}\right): \delta 1.17$ (4-Me, d, $J 7$ $\mathrm{Hz}), 3.87(\mathrm{H}-6, \mathrm{~m}), 4.09$ and $5.16\left(\mathrm{Ch}_{2} \mathrm{Ph}, J 15 \mathrm{~Hz}\right), 4.67(\mathrm{H}-5, \mathrm{~m}), 6.03(\mathrm{H}-4, \mathrm{dd}), 8.00$ (NH). MS(B): 203(100,M+H).

Method $B$. The reaction was allowed to proceed at room temperature for $24 \mathrm{~h}$. Only the isomer $2 b$ was isolated; yield $80 \%$.

Method C. After reaching room temperature the reaction was allowed to proceed for $2 \mathrm{~h}$ before being worked up. The yield of the isomer mixture was $77 \%$, the relative composition was $60 \%$ of $2 b$ and $40 \%$ of $4 b\left({ }^{1} \mathrm{H}\right.$ NMR).

1-Benzyl-5-chloro-3,4-dihydro-4-phenyl-2(1H)-pyrimidinone $2 \mathrm{c}$ and 1-benzyl-5-chloro3,6-dihydro-6-phenyl-2 $(1 \mathrm{H})$-pyrimidinone $4 \mathrm{c}$. Method $A$. The crude product from $1 b$ contained some biphenyl which was removed by recrystallization from ethyl acetate. The isomers were separated on neutral alumina or on silica gel using ethyl acetate for elution. In the latter case the 3,6-dihydro isomer is initially eluated, in the former case the order of elution is reversed. The yield was $7 \%$ of $2 c$ and $62 \%$ of $4 c$.

Physical data for $2 c$ : M.p. $110^{\circ} \mathrm{C}$ (EtOAc). Anal. $\mathrm{C}_{17} \mathrm{H}_{15} \mathrm{ClN}_{2} \mathrm{O}: \mathrm{C}, \mathrm{H}$. ${ }^{1} \mathrm{H}$ NMR $\left(\mathrm{CDCl}_{3}\right): \delta 4.58\left(\mathrm{CH}_{2} \mathrm{Ph}\right), 5.00(\mathrm{~h}-4, \mathrm{~d}, J 1.8 \mathrm{~Hz}), 5.43(\mathrm{NH}, \mathrm{d}), 6.13(\mathrm{H}-6) .{ }^{13} \mathrm{C}$ NMR $\left(\mathrm{CDCl}_{3}\right): \delta 50.0\left(\mathrm{CH}_{2} \mathrm{Ph}\right), 61.5\left(\mathrm{C}-4, J_{\mathrm{CH}} 145 \mathrm{~Hz}\right), 108.7(\mathrm{C}-5, \mathrm{~s}), 125.7\left(\mathrm{C}-6, J_{\mathrm{CH}} 182 \mathrm{~Hz}\right)$, 152.2 (C-2). IR $\left(\mathrm{CCl}_{4}\right): 1700 \mathrm{~cm}^{-1}$ (CO). MS(M): 301/299(30/94,M+H), 91(100).

Physical data for $4 c$ : M.p. $190{ }^{\circ} \mathrm{C}$ (EtOAc). Anal. $\mathrm{C}_{17} \mathrm{H}_{15} \mathrm{ClN}_{2} \mathrm{O}$ : C, H. ${ }^{1} \mathrm{H}$ NMR $\left(\mathrm{CDCl}_{3}\right): \delta 3.47$ and $5.30\left(\mathrm{CH}_{2} \mathrm{Ph}, \mathrm{AB}, J 15 \mathrm{~Hz}\right), 4.77(\mathrm{H}-6), 6.15(\mathrm{H}-4, \mathrm{~d}, J 6 \mathrm{~Hz}), 8.1(\mathrm{NH}$, d). ${ }^{13} \mathrm{C}$ NMR $\left(\mathrm{CDCl}_{3}\right): \delta 47.2\left(\mathrm{CH}_{2} \mathrm{Ph}\right), 63.9\left(\mathrm{C}-6, \mathrm{~d}, J_{\mathrm{CH}} 144 \mathrm{~Hz}\right), 107.3(\mathrm{C}-5, \mathrm{~s}), 121.7$ $\left(\mathrm{C}-4, \mathrm{~d}, J_{\mathrm{CH}} 182 \mathrm{~Hz}\right), 150.6(\mathrm{C}-2, \mathrm{~s})$. IR $\left(\mathrm{CCl}_{4}\right): 1675 \mathrm{~cm}^{-1}(\mathrm{CO})$. MS(M): 301/299(35/ $100, \mathrm{M}+\mathrm{H})$.

Method $B$. The yield was $53 \%$ of $2 c$ and $18 \%$ of $4 c$.

Method $C$. The yield of the isomer mixture was $75 \%$, with composition $23 \%$ of $2 c$ and $77 \%$ of $4 c$. 
1-Benzyl-5-chloro-3,4-dihydro-4-methyl-2(1H)-pyrimidinone $2 \mathrm{~d}$ and 1-benzyl-5-chloro3,6-dihydro-6-methyl-2(1H)-pyrimidinone $4 \mathrm{~d}$.

$\operatorname{Method} A$. The isomers were separated on neutral alumina. The yield was $41 \%$ of $2 d$ and $46 \%$ of $4 d$.

Physical data for $2 d$ : M.p. $117-119^{\circ} \mathrm{C}$ (EtOAc). Anal. $\mathrm{C}_{12} \mathrm{H}_{13} \mathrm{ClN}_{2} \mathrm{O}: \mathrm{C}, \mathrm{H} .{ }^{1} \mathrm{H}$ NMR $\left(\mathrm{CDCl}_{3}\right): \delta 1.36(4-\mathrm{Me}, \mathrm{d}, J 7 \mathrm{~Hz}), 4.17(\mathrm{H}-4, \mathrm{~m}), 4.55\left(\mathrm{CH}_{2} \mathrm{Ph}, \mathrm{s}\right), 5.67(\mathrm{NH}), 5.98(\mathrm{H}-6, \mathrm{~s})$. IR $\left(\mathrm{CCl}_{4}\right): 1690 \mathrm{~cm}^{-1} .{ }^{13} \mathrm{C}$ NMR $\left(\mathrm{CDCl}_{3}\right): \delta 22.5(\mathrm{Me}), 49.8\left(\mathrm{CH}_{2} \mathrm{Ph}\right), 52.8\left(\mathrm{C}-4, \mathrm{~d}, J_{\mathrm{CH}} 144\right.$ $\mathrm{Hz}$ ), 110.7 (C-5, s), 125.3 (C-6, d, J J $180 \mathrm{~Hz}$ ), 157.7 (C-2, s). MS(B): 239/237 $(24 / 75, \mathrm{M}+\mathrm{H}), 91(100)$.

Physical data for $4 d$ : Non-crystalline material which was dried under vacuum before analyses. Anal. $\mathrm{C}_{12} \mathrm{H}_{13} \mathrm{ClN}_{2} \mathrm{O}: \mathrm{C}, \mathrm{H}$. ${ }^{1} \mathrm{H}$ NMR $\left(\mathrm{CDCl}_{3}\right): \delta 1.28(6-\mathrm{Me}, \mathrm{d}, J 7 \mathrm{~Hz}), 3.85(\mathrm{H}-6$, $\mathrm{m}), 4.06$ and $5.06\left(\mathrm{CH}_{2} \mathrm{Ph}, \mathrm{AB}, J 15 \mathrm{~Hz}\right), 6.06(\mathrm{H}-4, \mathrm{~d}, J 5 \mathrm{~Hz}), 8.67(\mathrm{NH}){ }^{13} \mathrm{C}$ NMR $\left(\mathrm{CDCl}_{3}\right): \delta 17.4(\mathrm{Me}), 47.9\left(\mathrm{CH}_{2} \mathrm{Ph}\right), 56.2\left(\mathrm{C}-6, J_{\mathrm{CH}} 144 \mathrm{~Hz}\right), 108.0(\mathrm{C}-5, \mathrm{~s}), 152.2(\mathrm{C}-2, \mathrm{~s})$. IR (CCl $): 1680 \mathrm{~cm}^{-1}$ (CO). MS(B): $239 / 237(19 / 63, \mathrm{M}+\mathrm{H})$.

Method $B$. The yield was $65 \%$ of the isomer $2 d$ and $25 \%$ of $4 d$.

Method $C$. The yield of the isomer mixture was $80 \%$, with composition $60 \%$ of $2 d$ and $40 \%$ of $4 d$.

1-Benzyl-5-bromo-3,4-dihydro-4-phenyl-2(1H)-pyrimidinone $2 \mathrm{e}$ and 1-benzyl-5-bromo3,6-dihydro-6-phenyl-2(1H)-pyrimidinon 4e. Method A. The dihydroisomers prepared from $1 c^{15}$ were separated on neutral alumina. The yield was $30 \%$ of $2 e$ and $58 \%$ of $4 e$.

Physical data for $2 e$ : M.p. $136-138{ }^{\circ} \mathrm{C}$ (EtOAc). Anal. $\mathrm{C}_{17} \mathrm{H}_{15} \mathrm{BrN}_{2} \mathrm{O}: \mathrm{C}, \mathrm{H} .{ }^{1} \mathrm{H}$ NMR $\left(\mathrm{CDCl}_{3}\right): \delta 4.63\left(\mathrm{CH}_{2} \mathrm{Ph}\right), 5.08(\mathrm{H}-4, \mathrm{~m}), 5.53(\mathrm{NH}), 6.25(\mathrm{H}-6, \mathrm{~s}) . \mathrm{MS}(\mathrm{B}): 345 / 343$ $(100 / 100, \mathrm{M}+\mathrm{H})$.

Physical data for $4 e$ : M.p. $183-184{ }^{\circ} \mathrm{C}$ (EtOAc). Anal. $\mathrm{C}_{17} \mathrm{H}_{15} \mathrm{BrN}_{2} \mathrm{O}: \mathrm{C}, \mathrm{H} .{ }^{1} \mathrm{H}$ NMR $\left(\mathrm{CDCl}_{3}\right): \delta 3.50$ and $5.33\left(\mathrm{CH}_{2} \mathrm{Ph}, \mathrm{AB}, J 15 \mathrm{~Hz}\right), 4.78(\mathrm{H}-6, \mathrm{~m}), 6.42(\mathrm{H}-4, \mathrm{~d}, J 5 \mathrm{~Hz}), 8.40$ (NH). MS(B): 345/343 (98/100,M+H).

Method $B$. The yield was $56 \%$ of isomer $2 e$ and $19 \%$ of $4 e$.

Method $C$. The yield was $22 \%$ of isomer $2 e$ and $53 \%$ of $4 e$.

1-Benzyl-5-bromo-3,4-dihydro-4-methyl-2(1H)-pyrimidinone $2 \mathrm{f}$ and 1-benzyl-5-bromo3,6-dihydro-6-methyl-2(1H)-pyrimidinone 4f. Method $A$. The dihydro isomers from $1 c$ were separated on neutral alumina. The yield was $34 \%$ of $2 f$ and $50 \%$ of $4 f$.

Physical data for $2 f:$ M.p. $134{ }^{\circ} \mathrm{C}$ (EtOAc). Anal. $\mathrm{C}_{12} \mathrm{H}_{13} \mathrm{BrN}_{2} \mathrm{O}$ : $\mathrm{C}, \mathrm{H}$. ${ }^{1} \mathrm{H}$ NMR $\left(\mathrm{CDCl}_{3}\right): \delta 1.37(\mathrm{Me}, J 6 \mathrm{~Hz}), 4.25(\mathrm{H}-4, q, J 6 \mathrm{~Hz}), 4.62\left(\mathrm{CH}_{2} \mathrm{Ph}\right), 6.18(\mathrm{H}-6, \mathrm{~s}), 6.30(\mathrm{NH})$. MS(M): 283/281 (40/49,M+H).

Physical data for $4 f$ : M.p. 88-90 ${ }^{\circ} \mathrm{C}$ (decomp.; EtOAc). Anal. $\mathrm{C}_{12} \mathrm{H}_{13} \mathrm{BrN}_{2} \mathrm{O}: \mathrm{C}, \mathrm{H} .{ }^{1} \mathrm{H}$ NMR $\left(\mathrm{CDCl}_{3}\right): \delta 1.32(6-\mathrm{Me}, J 6 \mathrm{~Hz}), 3.61$ and $5.61\left(\mathrm{CH}_{2} \mathrm{Ph}, \mathrm{AB}, J 15 \mathrm{~Hz}\right), 3.93(\mathrm{H}-6, q, J 6$ $\mathrm{Hz}), 5.93(\mathrm{H}-4, \mathrm{~d}, J 5 \mathrm{~Hz}), 8.52(\mathrm{NH})$. MS(M): 283/281 (83/90,M+H).

Method $B$. The yield was $51 \%$ of isomer $2 f$ and $30 \%$ of $4 f$.

Method $C$. The yield was $51 \%$ of isomer $2 f$ and $29 \%$ of $4 f$.

1-Benzyl-3,4-dihydro-5-iodo-4-methyl-2(1H)-pyrimidinone $2 \mathrm{~g}$ and 1-benzyl-3,6-dihydro5 -iodo-6-methyl-2(1H)-pyrimidinone $4 \mathrm{~g}$. Method $A$. The reaction mixture from $1 d^{15}$ was stirred at room temperature for $3 \mathrm{~h}$ before being worked up. The isomers were separated by chromatography on alumina. The yield was $20 \%$ of isomer $2 g$ and $63 \%$ of $4 g$.

Physical data for $2 g$ : M.p. $134{ }^{\circ} \mathrm{C}$ (decomp.; EtOAc): Anal. $\mathrm{C}_{12} \mathrm{H}_{13} \mathrm{IN}_{2} \mathrm{O}$ : C, H. ${ }^{1} \mathrm{H}$ $\operatorname{NMR}\left(\mathrm{CDCl}_{3}\right): \delta 1.35(4-\mathrm{Me}, \mathrm{d}, J 6 \mathrm{~Hz}), 4.35(\mathrm{H}-4, q, J 6 \mathrm{~Hz}), 4.60\left(\mathrm{CH}_{2} \mathrm{Ph}\right), 5.56(\mathrm{NH})$, $6.26(\mathrm{H}-6, \mathrm{~s})$. MS(M): $329(95, \mathrm{M}+\mathrm{H}), 313(100)$.

Physical data for $4 g$ : M.p. $122-124{ }^{\circ} \mathrm{C}$ (EtOAc). Anal. $\mathrm{C}_{12} \mathrm{H}_{13} \mathrm{IN}_{2} \mathrm{O}: \mathrm{C}, \mathrm{H}$. ${ }^{1} \mathrm{H}$ NMR $\left(\mathrm{CDCl}_{3}\right): \delta 1.27(6-\mathrm{Me}, \mathrm{d}, J 6 \mathrm{~Hz}), 3.88(\mathrm{H}-6, q, J 6 \mathrm{~Hz}), 4.09$ and $5.06\left(\mathrm{CH}_{2} \mathrm{Ph}, \mathrm{AB}, J 16\right.$ $\mathrm{Hz}), 6.33(\mathrm{H}-4, \mathrm{~d}, J 5 \mathrm{~Hz}), 8.58(\mathrm{NH})$. MS(M): $329(100, \mathrm{M}+\mathrm{H}), 313(80)$.

Method $B$. Largely decomposition.

Method $C$. The yield of the isomer mixture was $68 \%$ with composition $44 \%$ of $2 g$ and $66 \%$ of $4 g$.

1-Benzyl-5-chloro-3,4-dihydro-4-ethyl-2(1H)-pyrimidinone $2 \mathrm{~h}$ and 1-benzyl-5-chloro-3,6dihydro-6-ethyl-2(1H)-pyrimidinone $4 \mathrm{~h}$. Method A. The compounds were prepared from $1 a$ as described for this method using ethylmagnesium iodide. The isomers were separated by chromatography on neutral alumina and chloroform. The yield was $41 \%$ of isomer $2 h$ and $50 \%$ of $4 h$. 
Physical data for $2 h$ : M.p. $83-85^{\circ} \mathrm{C}$ (EtOAc). Anal. $\mathrm{C}_{13} \mathrm{H}_{15} \mathrm{ClN}_{2} \mathrm{O}: \mathrm{C}$, H. ${ }^{1} \mathrm{H}$ NMR $\left(\mathrm{CDCl}_{3}\right): \delta 0.93$ and $1.67(\mathrm{Et}), 4.10(\mathrm{H}-4, \mathrm{~m}), 4.52\left(\mathrm{CH}_{2} \mathrm{Ph}\right), 6.03(\mathrm{H}-6, \mathrm{~s}), 6.90(\mathrm{NH})$. IR $\left(\mathrm{CCl}_{4}\right): 1690 \mathrm{~cm}^{-1}$ (CO). MS(M): 253/251 (33/100,M+H), 91(100).

Physical data for $4 h$ : M.p. $136^{\circ} \mathrm{C}$ (EtOAc). Anal. $\mathrm{C}_{13} \mathrm{H}_{15} \mathrm{ClN}_{2} \mathrm{O}: \mathrm{C}, \mathrm{H} .{ }^{1} \mathrm{H}$ NMR $\left(\mathrm{CDCl}_{3}\right): \delta 0.97$ and $1.66(\mathrm{Et}), 3.93(\mathrm{H}-6, \mathrm{t}, J 4 \mathrm{~Hz}), 4.34$ and $\left.5.56\left(\mathrm{CH}_{2} \mathrm{Ph}\right), \mathrm{AB}, J 15 \mathrm{~Hz}\right)$, $6.18(\mathrm{H}-4, \mathrm{~d}, J 5 \mathrm{~Hz}), 8.53(\mathrm{NH})$. IR $\left(\mathrm{CCl}_{4}\right): 1665 \mathrm{~cm}^{-1}(\mathrm{CO})$. MS(B): $253 / 251$ $(36 / 100, \mathrm{M}+\mathrm{H})$.

1-Benzyl-5-chloro-4-phenyl-2(1H)-pyrimidinone 3c. Activated manganese dioxide ${ }^{7}(5.0$ g) was added to a solution of 1-benzyl-5-chloro-3,4-dihydro-4-phenyl-2(1H)-pyrimidinone $(0.50 \mathrm{~g}, 1.7 \mathrm{mmol})$ in dry benzene $(50 \mathrm{ml})$ and the mixture stirred under nitrogen for $24 \mathrm{~h}$. The mixture was then filtered, the solid washed with benzene, the benzene solution and washings combined and the solvent evaporated. The residue was chromatographed on a silica gel column. Compound $3 c$ was eluated by ethyl acetate; yield $0.34 \mathrm{~g}(69 \%)$, m.p. 157-158 ${ }^{\circ} \mathrm{C}$ (EtOAc). Anal. $\mathrm{C}_{17} \mathrm{H}_{13} \mathrm{ClN}_{2} \mathrm{O}: \mathrm{C}, \mathrm{H} .{ }^{1} \mathrm{H}$ NMR $\left.\left(\mathrm{CDCl}_{3}\right): \delta 5.14\left(\mathrm{CH}_{2} \mathrm{Ph}\right), \mathrm{s}\right)$, 7.69 (H-6, s). MS(M): 299/297 (31/100,M+H). MS: 298/296 (11/33,M).

1-Benzyl-5-chloro-4-methyl-2 $(1 \mathrm{H})$-pyrimidinone $3 \mathrm{~d}$. Compound $3 d$ was prepared from $2 d$ and manganese dioxide ${ }^{7}$ as shown above. Heating is to be avoided during the removal of the solvent due to the ease of polymerization. The product was purified by chromatography on silica gel using ethyl acetate; yield $38 \%$, m.p. $127-129^{\circ} \mathrm{C}$ (EtOAc). Anal. $\mathrm{C}_{12} \mathrm{H}_{11} \mathrm{ClN}_{2} \mathrm{O}: \mathrm{C}, \mathrm{H}$. ${ }^{1} \mathrm{H}$ NMR $\left(\mathrm{CDCl}_{3}\right): \delta 2.42(4-\mathrm{Me}), 5.02\left(\mathrm{CH}_{2} \mathrm{Ph}\right), 7.08(\mathrm{Ph}), 7.60(\mathrm{H}-6)$. IR (KBr): $1660 \mathrm{~cm}^{-1}$. MS(M): $237 / 235(8 / 28, \mathrm{M}+\mathrm{H})$. MS: $236 / 234(16 / 49, \mathrm{M})$.

1-Benzyl-5-chloro-6-phenyl-2 $(1 \mathrm{H})$-pyrimidinone $5 \mathrm{c}$. Activated manganese dioxide ${ }^{7}(4.0$ g) was added to a solution of 1-benzyl-5-chloro-3,6-dihydro-6-phenyl-2(1H)-pyrimidinone $(0.30 \mathrm{~g}, 1.0 \mathrm{mmol})$ in dry benzene $(30 \mathrm{ml})$, and the mixture was stirred under nitrogen until TLC monitoring showed that the starting material had been consumed $(13 \mathrm{~d})$. The mixture was then filtered, the solid washed with benzene, the combined benzene solutions evaporated and the residue chromatographed on silica gel using ethyl acetate; yield $0.19 \mathrm{~g}$ $(64 \%)$, m.p. $125-127{ }^{\circ} \mathrm{C}$ (EtOAc). Anal. $\mathrm{C}_{17} \mathrm{H}_{13} \mathrm{ClN}_{2} \mathrm{O}: \mathrm{C}, \mathrm{H} .{ }^{1} \mathrm{H}$ NMR $\left(\mathrm{CDCl}_{3}\right): \delta 5.08$ $\left(\mathrm{CH}_{2} \mathrm{Ph}, \mathrm{s}\right), 8.65(\mathrm{H}-4, \mathrm{~s})$. IR $\left(\mathrm{CCl}_{4}\right): 1685 \mathrm{~cm}^{-1}(\mathrm{CO})$. MS(M): 299/297 (35/100,M+H).

\section{REFERENCES}

1. Elmoghayar, M.R.H. and Undheim, K. Acta Chem. Scand. B 37 (1983) 160.

2. Gacek, M., Undheim, K., Oftebro, R. and Laland, S.G. FEBS Lett. 98 (1979) 355.

3. Rise, F. and Undheim, K. Acta Chem. Scand. B 39 (1985) 195.

4. Hardtmann, G.E., Park, N.J.F. and Ott, H. U.S.Pat. 3.663 .698 (1972).

5. Coppola, G.M., Frazer, J.D., Hardtmann, G.E., Huegi, B.S. and Kathawala, F.G. J. Heterocycl. Chem. 16 (1979) 545.

6. Kashima, C., Katoh, A., Yokota, Y. and Omote, Y. J. Chem. Soc. Perkin. Trans. 1 (1981) 489.

7. Attenburrow, J., Cameron, A.F.B., Chapman, J.H., Evans, R.M. Hems, B.A., Jansen, A.B.A. and Walker, R. J. Chem. Soc. (1952) 1094.

8. Furberg, S. and Solbakk, J. Acta Chem. Scand. 24 (1970) 3230.

9. Furberg, S. Acta Chem. Scand. B 32 (1978) 478.

10. Gropen, O. and Skancke, P.N. Acta Chem. Scand. 24 (1970) 1768.

11. Doyle, P.A. and Turner, P.S. Acta Crystallogr. A 24 (1968) 390.

12. Stewart, R.F., Davidson, E.R. and Simpson, W.T. J. Chem. Phys. 42 (1965) 3175.

13. Groth, P. Acta Chem. Scand. 27 (1973) 1837.

14. Germain, G., Main, P. and Woolfson, M.M. Acta Crystallogr. A 27 (1971) 368.

15. Gacek, M. and Undheim, K. Acta Chem. Scand. B 35 (1981) 69.

Received September 12, 1984. 